\title{
Analysis and Countermeasures of Green Finance Development under Carbon Peaking and Carbon Neutrality Goals
}

\author{
Jianing Zhou \\ Nanjing Normal University, Nanjing, China \\ Email: aning0811@126.com
}

How to cite this paper: Zhou, J. N. (2022). Analysis and Countermeasures of Green Finance Development under Carbon Peaking and Carbon Neutrality Goals. Open Journal of Social Sciences, 10, 147-154. https://doi.org/10.4236/jss.2022.102009

Received: January 13, 2022

Accepted: February 14, 2022

Published: February 17, 2022

Copyright ( 2022 by author(s) and Scientific Research Publishing Inc. This work is licensed under the Creative Commons Attribution International License (CC BY 4.0).

http://creativecommons.org/licenses/by/4.0/

\begin{abstract}
Under the background of building ecological civilization and implementing the concept of green development, the construction of a green financial system has become the development direction of the financial industry. The development of green finance is a profound change in the financial industry. It is faced with multiple difficulties and problems, such as the lack of coordination in policies and standards, the insufficient product innovation capacity, and the imperfect international cooperation. Based on China's carbon peaking and carbon neutrality goals and related strategic deployment and guidance, this paper conducts an in-depth analysis of the existing problems and gives specific suggestions, in order to promote the steady development of green finance and contribute financial strength to promoting ecological progress and building a new development pattern.
\end{abstract}

\section{Keywords}

Green Finance, Carbon Peaking, Carbon Neutrality

\section{Introduction}

Climate change is one of the important factors leading to structural changes in the economic and financial system, and is attracting attention from central banks and financial institutions around the world (Tan \& Gao, 2020). Nowadays, industrial civilization at the cost of resource consumption, environmental pollution and ecological crisis is being replaced by ecological civilization. In September 2020, China clearly stated that its carbon dioxide emissions will peak by 2030 and strive to achieve its carbon neutrality target by 2060. Carbon peaking and carbon neutrality goals not only demonstrate China's efforts and contribution to 
tackling global climate change, but also meet the specific requirements of unswervingly implementing the new development concept (Liu, 2021). In October 2021, the CPC Central Committee and the State Council issued five documents, such as the Opinions on Completely, Accurately and Comprehensively Implementing the New Development Concept and Achieving Carbon Peaking and Carbon Neutrality Goals, comprehensively introducing China's low-carbon transformation measures to the world from different aspects. The realization of the "double carbon" goal involves the adjustment of industrial structure and energy structure, and has a significant impact on consumption and regional economic structure. Economic and social development will also undergo profound changes, a large amount of capital demand will emerge, and the strong support from the financial industry is particularly important. Under the "double carbon" goal, China's green finance development has entered a "fast track".

\section{Basic Concept of Green Finance}

\subsection{The Definition of Green Finance}

Green finance, different from traditional finance, emphasizes the living environment interests of human society as the core to carry out various financial activities. Green finance guide the economic subjects pay attention to the environmental protection, resource utilization and ecological balance, promoting sustainable development and construction of ecological civilization (Chen, 2021). In general, green finance refers to the economic activities taken to support environmental improvement, tackle climate change, solve resource crisis and other problems, including financial services such as green industry project investment and financing, project operation and risk management.

\subsection{The Significance of Green Finance}

\subsubsection{The Perspective of Ecological Civilization}

Green finance is of great significance to the construction of ecological civilization. On the one hand, the development of green finance is conducive to enhancing the domestic awareness of environmental protection, paying attention to environment and resource while pursuing economic benefits. On the other hand, green finance, based on the market, solves China's ecological problems through green investment and financing. It can continuously improve the country's ecological environment by supporting the development of green industry, and promote the allocation of financial resources to environmental protection, which is of strategic significance for improving the ecological environment and realizing green development.

\subsubsection{The Perspective of Economic Development}

Green finance has a positive role in promoting the sustainable economic development. On the one hand, green finance is an effective support for green technology innovation, and developing green finance can help contribute to green entrepreneurship. On the other hand, vigorously promoting green finance can 
transform the economic development mode, optimize the economic structure, realize the green transformation of China's economy, and promote high-quality economic development. The high-quality development of China's economy in reverse promotes the development of the domestic financial industry and further improves the external environment of the financial sector.

\section{The Development Situation and Prominent Problems of Green Finance}

\subsection{Lack of Coordination of Policies and Standards}

\subsubsection{The Policies Are Not Perfect Enough}

Some enterprises and departments have a weak awareness of the development of green finance. Local governments have not paid full attention to green finance since the early stage of green products tend to be high investment with low return. The coordination between various departments is insufficient, and the current green finance related policies are not compatible with fiscal and tax policies, which is not conducive to the effective implementation of policies. The policy docking and division of responsibilities and powers between relevant local government departments are also not clear, which is not conducive to giving full play to the leading role of policies.

\subsubsection{The Standards Are Not Unified Enough}

To develop green finance, we need to sort out China's green financial standards according to the actual conditions and improve them compared with international green financial standards. The "Equator Principles"1 and the "Green Bond Principles" 2 are the resource-based industry standards in the international project financing market. China's financial development has boomed in recent decades, but it still does not have very unified standards. As the concept of "green" is relatively macro and abstract, different departments have different definitions of the boundary of "green industry". This makes it difficult to exchange development experience with international financial institutions, thus reducing the speed of China's green finance development. It was not until 2019 that China issued the Green Industry Guidance Catalogue, making a clear definition of "green industry".

\subsection{Insufficient Product Innovation Ability}

\subsubsection{Small Number of Products with Single Variety}

Although China has initially established a green financial system, the number of green financial products is relatively small and of a single type. At present, the financing structure of green finance in China is still dominated by green credit, accounting for more than $90 \%$ of the total green financing scale (Han \& Du, 2021). For green bonds, China's green bond market has seen a strong growth ${ }^{1}$ Equator Principles refer to the criteria used to determine, measure, and manage social and environmental risks for project financing or credit crunch management.

${ }^{2}$ Green Bond Principles are the mainstream standards for green bonds issued by the Executive Committee on Green Bond Principles and the International Capital Markets Association. 
since its involvement in the market at the end of 2015. However, China's green bond market is dominated by the inter-bank market, in which green financial bonds are in the majority. To achieve the "double carbon" goal, China should also vigorously develop green stock indexes and related products, green development funds, green insurance, carbon finance and other financial instruments.

\subsubsection{The Application Scope of Products Is Limited}

At present, the application scope of Chinese green financial products and services is limited (An, Hou, \& Yang, 2017). Green credit and green bonds are in the main position in China's green financial products, but green financial instruments such as green insurance, green fund, green trust, green stocks, environmental equity pledge loan are relatively small. Due to lack of innovation and standardization, their application scope is very limited, and the support for green industry development is also limited. In addition, green finance is more focused on supporting the development of clean energy and other green industry, but seldom give effective support to energy, transportation, construction and other high carbon industry, which occupy a large proportion of China's economy and has a significant impact on the nation, to achieve low carbon transformation.

\subsubsection{Lack of Talent for Product Development}

Talent is the primary productive force and an important factor affecting the innovation of green financial products. Green finance is in the intersection area between various disciplines. Relevant personnel need not only the knowledge of finance and economy, but also a comprehensive grasp of the environment and other related knowledge. Chinese colleges and universities have not yet set up majors related to green finance. The talents specialized in finance or environmental protection is only familiar with the knowledge of their major, and cannot cross disciplines, so there is a large gap in compound talents.

\subsection{Imperfect International Cooperation}

Under China's "double carbon" goal, green finance development still needs to seek common ground while reserving differences in international cooperation. Although many countries are currently actively promoting the development of green finance to address climate change and achieve green recovery and sustainable development. However, due to the different stages of development, different international division of labor and industrial structure, and different ways and costs of tackling climate change, the international cooperation has difficulty in setting unified standards and designing suitable trading system. Such as carbon trading, an effective economic method to solve carbon emissions externalities, reached global carbon market trading consensus in the United Nations Framework Convention on Climate Change at the 26th session after six years' negotiation, and the actual implementation effect remains to be tested by practice. In addition to the complex trading mechanism and operation method car- 
bon market itself has, the large conflict of interest between developed and developing countries is difficult to reconcile. Therefore, in the process of green finance development, international cooperative relations still need to be coordinated.

\section{Suggestions on Solving the Development Problem of Green Finance}

\subsection{Establish and Improve the Green Finance System}

\subsubsection{Establish Policies and Standards Related to Green Finance}

To improve the green finance system, we must first form a unified green finance standard system and establish diversified policies. China needs to build laws and regulations related to green financial standards and give the overall development direction to the green finance market. We need to further strengthen policy guidance and improve the green financial system, including a green financial standard system that meets international standards, a mandatory information disclosure system, a scientific certification system, incentive mechanism and a risk control system. In addition, the government can support the infrastructure construction of green finance through expenditure, giving preferential interest rates to green industries and projects, setting restrictions on high polluting industries. Policy incentives and interest rate subsidies can attract more financial institutions and enterprises to make green investments.

\subsubsection{Clarify the Responsibility of Financial Institutions for Green Development}

Relevant departments should make it clear that financial institutions have the responsibility for green development (Wang \& Luo, 2020), and strengthen the awareness of green development of financial institutions. The government should establish a traceability environmental liability mechanism. If financial institutions make loans or invest in illegal environmental projects, financial institutions should be investigated or even bear the cost of paying off pollution because they bear joint and several liabilities. At the same time, green finance should be included in the evaluation framework. We need to support and guide banks and other financial institutions to establish a credit management system in line with the characteristics of green enterprises and projects, in order to optimize the credit approval process, increase support for green enterprises and projects on the premise that the risks are controllable, resolutely cancel unreasonable fees and reduce green credit costs.

\subsubsection{Improve the Design of the System for Promoting Green Development}

We need to further improve the system design to promote green development and create effective demand for financial institutions to carry out green financial services. A special committee or sustainable management department should be established to make strategic planning and deployment, formulate a timetable for financial institutions to support the "double carbon" goal, and further clarify 
the management philosophy and risk preferences for green and low-carbon development. According to the actual development situation, formulate local rules and standards for the development of green building and environmental protection industry; highlight the concept of green development, and promote enterprises and public implementation through legal means such as market entry threshold and fines; create green consumer demand to attract financial institutions into the green financial market.

\subsection{Support Innovation in Green Finance}

\subsubsection{Innovation in Financial Product Development}

Financial institutions should innovate and develop green finance-related products and services under the goal of "double carbon". Financial system should fully support the development of green industry and high carbon industry transformation, vigorously develop green credit and sustainable development linked credit. Under the premise of the business sustainable, commercial banks should refine green credit, carbon assets pledge loans, transform credit products, develop green financing instruments such as green bills, innovate credit financing guarantee methods. Accelerating innovation in green insurance products and increasing investment in green insurance can build a mandatory insurance system. At the same time, we should steadily promote the development of green bonds, green asset securitization, green leasing and other businesses, in order to form an all-round and multi-tiered green financial market system.

\subsubsection{Innovation in Practice of Financial Institutions}

First, strengthen innovation in financial risk management. All financial institutions need to conduct environmental risk supervision, build a green information sharing platform, improve the overall transparency of green finance, and reduce financial risks. For example, green financial support institutions should strictly follow the principle of risk avoidance in product innovation and the launch of new businesses, and design a variety of alternative financial and insurance services and products for related industries to meet the needs of the healthy and safe development of the industry. Second, strengthen the innovation in the financial service management. Strengthen the innovation of service standards. To be specific, we can formulate perfect service quality standards and introduce the international quality certification system. The overall service level can also be improved through innovative service content and innovative service means, among which the innovative service content should pay attention to the transformation of service to function, synthesis and humanity, and the innovative service means should start from the improvement of network service.

\subsubsection{Innovation in Green Financial Technology}

Technology will enhance the vitality of green finance and improve the efficiency of the green finance market. The development of the new generation of information technologies, such as artificial intelligence, blockchain, cloud computing, big data, and the Internet of Things, has brought about the explosive develop- 
ment of green financial technology, and brought revolutionary changes to the financial market and financial services. The Internet and cloud computing reduce the cost of green finance, and constitute a faster, rapid and simple green finance development model. Using big data technology can establish a green credit evaluation system and a green financial information platform, collecting environmental information, conducting data analysis in real time, reducing financial risks, and providing effective support for environmental regulatory authorities. Therefore, it is necessary to vigorously promote the financial technology sector and financial technology companies to enter the green financial market and help the development of green financial industry flourish.

\subsection{Deepen International Cooperation in Green Finance}

\subsubsection{Connect with International Standards}

First and foremost, we should continue to promote the research and formulation of globally unified sustainable classification standards and environmental information disclosure standards. Therefore, countries can refine and expand them on this basis to expand the global influence of green finance. In addition, market entities are encouraged to use the IPSF Common Classification Catalogue to issue green financial products, further connecting the Chinese and foreign markets and reducing domestic green financing costs. What's more, we should strengthen international exchanges and cooperation in green finance, play a positive role in the formulation of international rules, and tell China's story well. China should take "Belt and Road" as an important platform for international cooperation in green development, unify green definition standards, improve the regulatory and assessment system, actively participate in international organizations, promote the formulation of green rules in line with international standards, and explore new models, new paths and new mechanisms for financial support for carbon peaking and carbon neutrality goals.

\subsubsection{Strengthen International Transactions}

Support green investment in relevant countries and promote international cooperation in green finance through the Paris Agreement, the Belt and Road initiative, the Shanghai Cooperation Organization, and the Asian Infrastructure Investment Bank. We should actively promote the two-way opening up of the green securities market, support Chinese financial institutions and enterprises in issuing green bonds overseas, support international financial organizations and multinational corporations in issuing green bonds in China, set up joint venture green development funds, and carry out green investment (Wang, 2021). In addition, the EU carbon market is the most comprehensive and representative carbon market in the world. Promoting China-EU carbon trading will help to absorb the advanced experience of the EU carbon market, introduce carbon financial products and form effective carbon prices, improve the domestic carbon market, and give full play to the important role of the carbon market in the process of emission reduction (Wang \& Zhang, 2021). 


\section{Conclusion}

To sum up, the financial industry should conform to the historical trend and the trend of The Times. Under the "double carbon" goal, in the process of implementing the sustainable development strategy and building ecological civilization, the financial industry should make clear their roles, rise difficulties, seek change, and turn risks into opportunities. We should establish and improve the green finance system, vigorously support innovation in green finance, and deepen international cooperation in green finance, so as to provide financial support and contribute to promoting ecological progress, building a beautiful China, and building a new pattern of development. It is believed that more and more dynamic green finance will become an inexhaustible driving force for promoting the green and low-carbon transformation, and further promote sustainable economic development in China. This paper gives the analysis and countermeasures of green finance development theoretically, but there is still a lack of data analysis and specific case analysis, which needs further research in the future.

\section{Conflicts of Interest}

The author declares no conflicts of interest regarding the publication of this paper.

\section{References}

An, T. X., Hou, X. M., \& Yang, Y. (2017). Research on Theoretical Connotation and Realization Path of Green Finance Development in China. Dongyue Collection of Essays, 6, 92-100.

Chen, Y. W. (2021). Research on Development and Innovation of Green Finance. Modern Business, 33, 118-120.

Han, Y. Q., \& Du L. J. (2021). Green Finance Supports the Path Selection of Green Technology Innovation. Journal of North China University of Science and Technology (Social Science Edition), 6, 48-53.

Liu, Q. J. (2021). Around the "Double Carbon" Strategy with Green Finance to Help Regional Green Development. Contemporary Financiers, 11, 53-54.

Tan, L., \& Gao, J. L. (2020). Research on the Mechanism and Countermeasures of Climate Change Risk on Financial System. Financial Development Studies, 3, 13-20.

Wang, D. H., \& Luo, Z. C. (2020). Building a Diversified Support System for Green Financial Market. People, 10, 23-24.

Wang, N. (2021). Development Problems and Countermeasures of Green Finance. Modern Finance Guide, 11, 41-45.

Wang, Y., \& Zhang, N. (2021). Practice and Perfection of Green Finance to Promote Carbon Neutrality and Sustainable Development. China Economic Review, Z1, 24-27. 